\title{
Kejadian Anemia pada Ibu Hamil Ditinjau dari Paritas dan Usia
}

\author{
Willy Astriana \\ Program Studi DIII Kebidanan STIKES Al-Ma'arif Baturaja \\ Jl. Dr. Mohammad Hatta No. 687 B Baturaja \\ Email:willy.astriana@gmail.com
}

\begin{abstract}
ABSTRAK
Anemia merupakan masalah kesehatan masyarakat terbesar di dunia terutama bagi kelompok wanita usia reproduksi (WUS). Menurut WHO secara global prevalensi anemia pada ibu hamil di seluruh dunia adalah sebesar 41, $8 \%$. Salah satu penyebab anemia pada kehamilan yaitu paritas dan umur ibu. Penelitian ini menggunakan metode analitik dengan pendekatan cross sectional. Populasi dalam penelitian adalah seluruh ibu hamil di Wilayah Kerja UPTD Puskesmas Tanjung Agung Kabupaten OKU pada periode Agustus - Oktober 2017 didapatan sampel berjumlah 277 orang. Analisa data menggunakan uji statistik Chi-Square, dengan derajat kepercayaan 95\%. Pada analisa univariat, Dari 277 responden yang mengalami kejadian anemia pada ibu hamil sebanyak 118 responden (42, 6\%) dan 159 responden (57, 4\%) yang tidak mengalami kejadian anemia pada ibu hamil, paritas beresiko sebanyak 226 responden $(81,6 \%)$ dan paritas tidak beresiko sebanyak 51 responden (18, 4\%), umur beresiko sebanyak 199 responden (71, 8\%) dan umur tidak beresiko sebanyak 78 responden $(28,2 \%)$. Analisa statistik menunjukkan adanya korelasi antara kejadian anemia pada ibu hamil dengan paritas ( $p$ value 0,023) dan usia (p value 0, 028). Petugas kesehatan diharapkan dapat melakukan promosi kesehatan dengan memberikan informasi tentang pentingnya mengkonsumsi tablet zat besi yang tepat, makan makanan yang mengandung sumber zat besi, dan pentingnya vitamin $C$ untuk meningkatkan penyerapan zat besi di dalam tubuh.
\end{abstract}

Kata Kunci: Kejadian Anemia, Ibu Hamil, Paritas, Usia

THE OCCURRENCE OF ANEMIA IN PREGNANT WOMEN BASED ON PARITY AND AGE

\begin{abstract}
Anemia is the largest public health problem in the world, especially for women of reproductive age. According to WHO globally the prevalence of anemia in pregnant women around the world is $41,8 \%$. One of the causes of anemia in pregnancy is parity and maternal age. This research use analytical method with cross sectional approach. The population in this study were all pregnant women in the working area of UPTD Puskesmas Tanjung Agung OKU period August - Ocktober, and a sample of 277 people. Data analysis using univariate analysis and bivariate analysis using distribution tables and Chi-Square statistical test, with 95\% confidence degree. In the univariate analysis, 277 respondents who experienced anemia incidence in pregnant women were 118 respondents $(42,6 \%)$ and 159 respondents $(57,4 \%)$ who did not experience anemia in pregnant mother, the risk parity was 226 respondents (81, 6\%) and parity is not risk as much 51 respondent (18, 4\%), age at risk as much as 199 respondent (71, 8\%) and age not risk as much 78 respondents (28, 2\%) Statistical analysis showed a correlation between the incidence of anemia in pregnant women with parity ( $p$ value 0,023) and age ( $p$ value 0.028). Healthcare workers are expected to conduct health promotion by providing information on the importance of taking proper ferrum tablets, eating foods containing ferrum sources, and the importance of vitamin $C$ to increase absorption of ferrum in the body.
\end{abstract}

Keywords: Occurrence of Anemia, Pregnant Mother, Parity, Age of Mother

How to Cite: Astriana, Willy. (2017). Kejadian Anemia pada Ibu Hamil Ditinjau dari Paritas Dan Usia. Jurnal Aisyah: Jurnal Ilmu Kesehatan. 2 (2), 123 - 130. 


\section{PENDAHULUAN}

Anemia adalah suatu keadaan dimana tubuh memiliki jumlah sel darah merah (eritrosit) yang terlalu sedikit, yang mana sel darah merah itu mengandung hemoglobin yang berfungsi untuk membawa oksigen ke seluruh jaringan tubuh (Proverawati, 2013). Menurut WHO (2008), secara global prevalensi anemia pada ibu hamil di seluruh dunia adalah sebesar 41, $8 \%$. Prevalensi anemia pada ibu hamil diperkirakan di Asia sebesar 48,2 \%, Afrika 57,1 \%, Amerika 24,1 \%, dan Eropa 25,1 \%. (Salmariantity, 2012).

Berdasarkan hasil Riset Kesehatan Dasar (Riskesdas) tahun 2013, prevalensi anemia pada ibu hamil di Indonesia sebesar 37, 1 $\%$. Pemberian tablet $\mathrm{Fe}$ di Indonesia pada tahun 2012 sebesar $85 \%$. Presentase ini mengalami peningkatan dibandingkan pada tahun 2011 yang sebesar 83,3\%. Meskipun pemerintah sudah melakukan program penanggulangan anemia pada ibu hamil yaitu dengan memberikan 90 tablet $\mathrm{Fe}$ kepada ibu hamil selama periode kehamilan dengan tujuan menurunkan angka anemia ibu hamil, tetapi kejadian anemia masih tinggi (Kementerian Kesehatan RI, 2013).

Anemia merupakan masalah kesehatan masyarakat terbesar di dunia terutama bagi kelompok wanita usia reproduksi (WUS). Anemia pada wanita usia subur (WUS) dapat menimbulkan kelelahan, badan lemah, penurunan kapasitas/kemampuan atau produktifitas kerja. Penyebab paling umum dari anemia pada kehamilan adalah kekurangan zat besi, asam folat, dan perdarahan akut dapat terjadi karena interaksi antara keduanya (Noverstiti, 2012).

Asuhan pelayanan kebidanan dalam mencegah komplikasi pada masa kehamilan maupun persalinan dilakukan dengan pemeriksaan darah yang dilakukan minimal dua kali selama kehamilan, yaitu pada trimester 1 dan trimester 3. Dari pengamatan yang dilakukan oleh
Simanjuntak mengemukakan bahwa sekitar $70 \%$ ibu hamil di Indonesia menderita anemia kekurangan gizi dan kebanyakan anemia yang diderita oleh masyarakat salah satunya karena kehamilan dan persalinan dengan jarak yang berdekatan, ibu hamil dengan pendidikan dan tingkat sosial ekonomi yang rendah (Nurjanah dkk, 2012).

Anemia pada kehamilan tidak dapat dipisahkan dengan perubahan fisiologis yang terjadi selama proses kehamilan, umur janin, dan kondisi ibu hamil sebelumnya. Pada saat hamil, tubuh akan mengalami perubahan yang signifikan, jumlah darah dalam tubuh meningkat sekitar $20-30 \%$, sehingga memerlukan peningkatan kebutuhan pasokan besi dan vitamin untuk membuat hemoglobin $(\mathrm{Hb})$. Ketika hamil, tubuh ibu akan membuat lebih banyak darah untuk berbagi dengan bayinya. Tubuh memerlukan darah hingga $30 \%$ lebih banyak dari pada sebelum hamil (Noverstiti, 2012).

Beberapa faktor yang dapat menyebabkan terjadinya anemia kehamilan diantaranya gravid, umur, paritas, tingkat pendidikan, status ekonomi dan kepatuhan konsumsi tablet Fe (Keisnawati, dkk, 2015).

Faktor umur merupakan faktor risiko kejadian anemia pada ibu hamil. Umur seorang ibu berkaitan dengan alat - alat reproduksi wanita. Umur reproduksi yang sehat dan aman adalah umur 20 - 35 tahun. Kehamilan diusia $<20$ tahun dan diatas 35 tahun dapat menyebabkan anemia karena pada kehamilan diusia $<20$ tahun secara biologis belum optimal emosinya cenderung labil, mentalnya belum matang sehingga mudah mengalami keguncangan yang mengakibatkan kurangnya perhatian terhadap pemenuhan kebutuhan zat - zat gizi selama kehamilannya. Sedangkan pada usia $>35$ tahun terkait dengan kemunduran dan penurunan daya tahan tubuh serta berbagai penyakit yang sering menimpa diusia ini. Hasil penelitian didapatkan bahwa umur ibu pada saat hamil sangat 


\section{Jurnal Aisyah: Jurnal Ilmu Kesehatan 2 (2) 2017, - 125 \\ Willy Astriana}

berpengaruh terhadap kajadian anemia (Amirrudin dan Wahyuddin, 2014).

Paritas merupakan salah satu faktor penting dalam kejadian anemia zat besi pada ibu hamil. Menurut Manuaba (2010), wanita yang sering mengalami kehamilan dan melahirkan makin anemia karena banyak kehilangan zat besi, hal ini disebabkan selama kehamilan wanita menggunakan cadangan besi yang ada di dalam tubuhnya (Salmariantyty, 2012).

Anemia kehamilan disebut "potential danger to mother and child" (potensial membahayakan ibu dan anak). Dampak dari anemia pada kehamilan dapat terjadi abortus, persalinan pre $\neg$ maturitas, hambatan tumbuh kembang janin dalam rahim, mudah terjadi infeksi, perdarahan antepartum, ketuban pecah dini (KPD), saat persalinan dapat mengakibatkan gangguan His, kala pertama dapat berlangsung lama, dan terjadi partus terlantar, dan pada kala nifas terjadi subinvolusi uteri menimbulkan perdarahan pospartum, memudahkan infeksi puerperium, dan pengeluarkan AS1 berkurang (Aryanti dkk, 2013).

Data dari Dinas Kesehatan Kabupaten OKU tahun 2016 jumlah ibu dengan anemia dalam kehamilan sebanyak 11,9 \%. Sedangkan data UPTD Puskesmas Tanjung Agung tahun 2016 jumlah ibu dengan hamil sebanyak 903 orang dimana $12,4 \%$ dengan anemia dalam kehamilan.

Berdasarkan data peningkatan kejadian anemia, dampak yang dapat timbul dari kejadian anemia serta beberapa faktor yang berhubungan dengan kejadian anemia, maka penulis tertarik untuk melakukan penelitian mengenai hubungan antara paritas dan umur ibu dengan anemia pada ibu hamil.

\section{METODE PENELITIAN}

Dalam penelitian ini peneliti menggunakan metode survey analitik dengan pendekatan cross sectional, dimana data variabel independen dan perilaku Ibu serta variabel dependen dikumpulkan secara bersama (Notoatmodjo, 2012). Populasi penelitian ini adalah seluruh ibu hamil di Wilayah Kerja UPTD Puskesmas Tanjung Agung Kabupaten OKU periode Agustus Oktober 2017. Pada penelitian ini pengambilan sampel menggunakan rumus Notoatmodjo (2010), teknik pengambilan sampel dengan random sampling dan didapatkan sampel sebanyak 277 responden. Lokasi penelitian ini dilakukan di Wilayah Kerja UPTD Puskesmas Tanjung Agung Kabupaten OKU. Data diperoleh dengan melakukan penelitian secara studi dokumentasi dan menggunakan Checklist.

Analisa data menggunakan analisa data univariat dan bivariat. Analisa dilakukan dengan tabulasi silang dan uji statistik dengan menggunakan rumus Chi Square dengan derajat kepercayaan $95 \%$ bila $\mathrm{p}$ value $\leq 0,05$ menunjukkan hubungan bermakna dan tidak bermakna jika $\mathrm{p}$ value $>0,05$.

\section{HASIL DAN PEMBAHASAN}

Tabel 1. Distribusi Frekuensi Variabel Penelitian

\begin{tabular}{lcc}
\hline \multicolumn{1}{c}{ Variabel } & Frekuensi & \% \\
\hline $\begin{array}{l}\text { Kejadian anemia } \\
\text { Ya }\end{array}$ & 118 & 42,6 \\
Tidak & 159 & 57,4 \\
\hline Paritas & & \\
$\quad$ Beresiko & 226 & 81,6 \\
$\quad$ Tidak Beresiko & 51 & 18,4 \\
\hline Usia & & \\
Beresiko & 199 & 71,8 \\
Tidak Beresiko & 78 & 28,2 \\
\hline
\end{tabular}

Tabel 1 menunjukkan bahwa dari 277 responden yang mengalami kejadian anemia pada ibu hamil sebanyak 118 responden $(42,6 \%)$ dan sisanya 159 responden $(57,4 \%)$ yang tidak mengalami kejadian anemia pada ibu hamil. Responden dengan paritas beresiko sebanyak 226 responden $(81,6 \%)$ dan paritas tidak beresiko sebanyak 51 responden $(18,4 \%)$. Responden dengan umur beresiko sebanyak 
Jurnal Aisyah: Jurnal Ilmu Kesehatan 2 (2) 2017, - 126

Willy Astriana

199 responden $(71,8 \%)$ dan umur tidak beresiko sebanyak 78 responden $(28,2 \%)$.

Tabel 2. Hubungan paritas dengan kejadian anemia pada ibu hamil.

\begin{tabular}{|c|c|c|c|c|c|c|c|}
\hline \multirow{3}{*}{ Paritas } & \multicolumn{4}{|c|}{ Kejadian anemia pada ibu hamil } & \multirow{3}{*}{$\Sigma$} & \multirow{3}{*}{$\%$} & \multirow{3}{*}{ p value } \\
\hline & \multicolumn{2}{|c|}{ Ya } & \multicolumn{2}{|c|}{ Tidak } & & & \\
\hline & f & $\%$ & f & $\%$ & & & \\
\hline Beresiko & 104 & 46,0 & 122 & 54,0 & 266 & 100 & \\
\hline Tidak Beresiko & 14 & 27,5 & 37 & 72,5 & 51 & 100 & 0,023 \\
\hline Jumlah & 118 & 42,6 & 159 & 57,4 & 277 & 100 & \\
\hline
\end{tabular}

Tabel 2. menunjukkan bahwa 118 responden yang mengalami kejadian anemia pada ibu hamil dengan paritas beresiko berjumlah 104 responden $(46,0 \%)$ lebih besar dibandingkan responden dengan paritas tidak beresiko yaitu 14 responden $(27,5 \%)$.
Hasil uji statistik Chi-Square di dapatkan $p$ value $0,023(\mathrm{p}<0,05)$. Ini menunjukkan menunjukkan ada hubungan yang bermakna antara paritas dengan kejadian anemia pada ibu hamil. Maka hipotesa yang menyatakan bahwa ada hubungan yang bermakna antara paritas dengan kejadian anemia pada ibu hamil terbukti.

Tabel 3. Hubungan umur dengan kejadian anemia pada ibu hamil.

\begin{tabular}{|c|c|c|c|c|c|c|c|}
\hline \multirow{3}{*}{ Umur } & \multicolumn{4}{|c|}{ Kejadian anemia pada ibu hamil } & \multirow{3}{*}{$\Sigma$} & \multirow{3}{*}{$\%$} & \multirow{3}{*}{ p value } \\
\hline & \multicolumn{2}{|c|}{$\mathbf{Y a}$} & \multicolumn{2}{|c|}{ Tidak } & & & \\
\hline & $\mathbf{f}$ & $\%$ & $\mathbf{f}$ & $\%$ & & & \\
\hline Beresiko & 94 & 47,2 & 105 & 52,8 & 199 & 100 & \\
\hline Tidak Beresiko & 24 & 30,8 & 54 & 69,2 & 78 & 100 & 0,018 \\
\hline Jumlah & 118 & 42,6 & 159 & 57,4 & 277 & 100 & \\
\hline
\end{tabular}

Tabel 3. menunjukkan bahwa dari 118 responden yang mengalami kejadian anemia dengan usia beresiko yaitu 94 responden (47,2\%) lebih besar dibandingkan responden dengan usia tidak bersiko yaitu 24 responden (30,8\%).

Hasil uji statistik Chi-Square di dapatkan $p$ value $0,018(\mathrm{p}<0,05)$. Ini menunjukkan bahwa terdapat hubungan yang bermakna antara umur dengan kejadian anemia pada ibu hamil.

Berdasarkan hasil analisis maka hipotesa yang diajukan diterima, yaitu terdapat hubungan yang bermakna antara umur dengan kejadian anemia pada ibu hamil.

Hubungan paritas dengan kejadian anemia pada ibu hamil.
Pada penelitian ini variabel umur dikategorikan menjadi beresiko dan tidak beresiko. Dari hasil penelitian didapatkan dari 118 responden yang mengalami kejadian anemia pada ibu hamil dengan paritas beresiko yaitu 104 responden (46,0\%) lebih besar dibandingkan responden dengan paritas tidak bersiko yaitu 14 responden $(27,5 \%)$.

Hasil uji statistik Chi-Square di dapatkan $p$ value 0,023 ini menunjukkan menunjukkan ada hubungan yang bermakna antara paritas dengan kejadian anemia pada ibu hamil. Maka hipotesa yang menyatakan bahwa ada hubungan yang bermakna antara paritas dengan kejadian anemia pada ibu hamil di UPTD Puskesmas tanjung Agung Tahun 2017 terbukti. 


\section{Jurnal Aisyah: Jurnal Ilmu Kesehatan 2 (2) 2017, - 127}

Willy Astriana

Hasil penelitian ini hasil sesuai dengan penelitian Salmariantity (2012) menunjukkan hubungan paritas dengan kejadian anemia pada ibu hamil dengan nilai uji statistik terbukti signifikan $p$ value $=0,029<0,05$ dengan nilai Prevalance Ratio $(\mathrm{PR})=1,64$ dan 95\% CI antara 1,03 2,8 .

Berdasarkan hasil penelitian didapatkan bahwa responden dengan paritas beresiko lebih banyak mengalami anemia pada ibu hamil dibandingkan responden dengan paritas tidak beresiko. Menurut peneliti hal ini dikarenakan Paritas merupakan salah satu faktor penting dalam kejadian anemia zat besi pada ibu hamil.

Pengaruh anemia dalam kehamilan dapat berakibat fatal jika tidak segera di atasi di antaranya dapat menyebabkan keguguran, partus prematus, inersia uteri, partus lama, atonia uteri dan menyebabkan perdarahan serta syok. Sedangkan pengaruh anemia terhadap kosepsi diantaranya dapat menyebabkan keguguran, kematian janin dalam kandungan, kematian janin waktu lahir, kematian perinatal tinggi, prematuritas dan cacat bawaan. Anemia kehamilan dapat dipengaruhi oleh gravida. Hasil penelitian Ridayanti (2012), menyebutkan bahwa ibu hamil primigravida yang mengalami anemia kehamilan sebesar $44,6 \%$ sedangkan ibu multigravida yang mengalami anemia kehamilan sebesar $12,8 \%$. Hal tersebut disebabkan ibu primigravida belum mempunyai pengalaman untuk menjaga kesehatan kehamilan dari kehamilan sebelumnya karena baru pertama kali hamil (Farsi, 2011).

\section{Hubungan umur dengan kejadian anemia pada ibu hamil.}

Pada penelitian ini variabel paritas dikategorikan menjadi beresiko dan tidak beresiko Dari hasil penelitian didapatkan dari 118 responden yang mengalami kejadian anemia pada ibu hamil dengan umur beresiko yaitu 94 responden $(47,2 \%)$ lebih besar dibandingkan responden dengan umur tidak bersiko yaitu 24 responden $(30,8 \%)$.

Hasil uji statistik Chi-Square di dapatkan $p$ value 0,018 ini menunjukkan menunjukkan ada hubungan yang bermakna antara umur dengan kejadian anemia pada ibu hamil. Maka hipotesa yang menyatakan menunjukkan bahwa ada hubungan yang bermakna antara umur dengan kejadian anemia pada ibu hamil di UPTD Puskesmas tanjung Agung Tahun 2017 terbukti.

Hasil penelitian ini sesuai dengan penelitian Salmariantity (2012) menunjukkan hubungan umur dengan kejadian anemia pada ibu hamil dengan nilai uji statistik terbukti signifikan $\mathrm{p}$ value $=0,012<0,005$ dengan nilai Prevalance Ratio (PR) $=1,8$ dan 95\% CI antara 1,07 - 3,28 yang artinya ibu hamil pada umur beresiko ( $<20$ Tahun) berpeluang mendapatkan anemia 1,8 kali dibandingkan dengan ibu hamil pada umur tidak beresiko (20 - 35 Tahun).

Berdasarkan hasil penelitian didapatkan bahwa responden dengan umur beresiko lebih banyak mengalami anemia pada ibu hamil dibandingkan responden dengan umur tidak beresiko. Menurut peneliti hal ini dikarenakan Kehamilan diusia $<20$ tahun dan diatas 35 tahun dapat menyebabkan anemia karena pada kehamilan diusia $<20$ tahun secara biologis belum optimal emosinya cenderung labil, mentalnya belum matang sehingga mudah mengalami keguncangan yang mengakibatkan kurangnya perhatian terhadap pemenuhan kebutuhan zat-zat gizi selama kehamilannya. Sedangkan pada usia $>35$ tahun terkait dengan kemunduran dan penurunan daya tahan tubuh serta berbagai penyakit yang sering menimpa diusia ini.

\section{KESIMPULAN DAN SARAN}

Berdasarkan hasil penelitian tentang karekteristik ibu hamil ditinjau dengan kejadian anemia di Wilayah Kerja UPTD Pusesmas Tanjung Agung pada Tahun 2017 
disimpulkan adanya hubungan paritas dan umur ibu dengan kejadian anemia pada ibu hamil dengan nilai $p$ value 0,023 dan 0,028 .

Diharapkan tenaga kesehatan khususnya petugas kesehatan dalam melakukan promosi kesehatan khususnya promosi pada ibu hamil lebih menekankan pada perubahan-perubahan yang terjadi pada ibu hamil khususnya promosi anemia ibu hamil dan cara meminum tablet zat besi salah satunya dengan sosialisasi pentingnya konsumsi tablet zat besi yang tepat, makan makanan yang mengandung sumber zat besi, dan pentingnya vitamin $\mathrm{C}$ untuk meningkatkan penyerapan tablet zat besi di dalam tubuh.

Di harapkan agar dapat meneliti variabel lainnya yang lebih bervariasi dan mencakup penelitian yang lebih luas dengan metode penelitian yang berbeda terutama yang berhubungan dengan kejadian anemia pada ibu hamil sehingga penelitian dapat terus di kembangkan. 


\section{DAFTAR PUSTAKA}

Amirudin, Wahyuddin, 2014, Studi Kasus Kontrol Faktor Biomedis Terhadap Kejadian Anemia Ibu Hamil di Puskesmas Bantimurung Maros, Jurnal Medika Nusantara. Vol. 25 No. 2.

Aryanti Wardiah, Sumini Setiawati, Riyani, Riska Wandiri, Lidya Aryanti. (2013). Faktor-faktor yang mempengaruhi kejadian anemia pada ibu hamil di wilayah kerja Puskesmas Sekampung Kabupaten Lampung Timur tahun 2013. Bandarlampung: PSIK Universitas Malahayati.

Darlina. (2011). Faktor Risiko Anemia Pada Ibu Hamil di Bogor. Bandung: Media Gizi dan Keluarga.

Evelyn. (2010). Faktor-faktor yang berhubungan dengan kejadian Anemia. Kemenkes Manado.

Cunninggham, Leveno, Bloom, Hauth, Rouse \& Spong. (2013). Obstetri Williams. Jakarta: EGC.

Emilia. (2015). Asuhan pada ibu hamil, Yogyakarta: Pustaka Rihanga.

Farsi, Y., Brooks, D., Werler, M., Cabral, H., Al-Syafei, M., \& Wallenburg, H. C. (2011). Effect of High Parity on Occurence of Anemia in Pregnancy: a Cohort Study. BMC Pregnancy and Childbirth, 11(7), 7.

Kautsar., Damanik, M. R. (2011). Hubungan antara Intensitas Pemeriksaan Kehamilan, Fasilitas Pelayanan Kesehatan, dan Konsumsi Tablet Besi dengan Tingkat Keluhan selama Kehamilan. Jurnal Gizi dan Pangan. 3(1): 1221.
Krisnawati., Desi Ari Madi Yanti., Apri Sulistianingsih. (2015). Faktorfaktor terjadinya anemia pada ibu primigravida di wilayah kerja Puskesmas tahun 2015. STIKES Peringsewu Lampung.

Kementrian Kesehatan RI. (2015). Buku Ajar Kesehatan Ibu dan Anak. Jakarta: Pusat Pendidikan dan Pelatihan Tenaga Kesehatan.

Khumaira. (2012). Faktor-faktor yang Berhubungan dengan Kepatuhan Ibu Hamil Mengkonsumsi Tablet Fe. Bandung: FKM-UNSIL.

Manuaba, I. B. G. (2012). Buku Ajar Phantom Obstetri. Jakarta: Trans Info Media.

Mansjoer, Arif. (2013). Buku Saku Untuk Bidan. Jakarta: Nuha Medika.

Mochtar, M. A. (2012). Buku Saku Untuk Bidan. Jakarta: Nuha Medika.

Notoatmodjo, Soekidjo. (2012). Promosi Kesehatan Ilmu dan Perilaku. Jakarta: Rineka Cipta.

Notoatmodjo, Soekidjo. (2010). Metode Penelitian Kesehatan. Jakarta: Rineka Cipta.

Noverstiti, Elsy. (2012). Faktor-faktor yang Berhubungan dengan Kejadian Anemia pada Ibu Hamil Trimester III di Wilayah Kerja Puskesmas Air Dingin Kota Padang tahun 2012. STIKES Peringsewu Lampung.

Ningrum. (2016). Manfaat Tablet Fe Bagi Ibu Hamil. Padang: FK UNAND.

Nyoman, A. I. (2011). Faktor-Faktor yang Mempengaruhi Kejadian Anemia pada Remaja dan Dewasa di DKI Jakarta tahun 2007. Bogor: Institut Pertanian Bogor. 
Saifuddin, A. (2012). Pelayanan Kesehatan Maternal dan Neonatal. Jakarta: JNPKKR Dan Yayasan Bina Pustaka.

Salmariantity. (2012). Faktor- faktor yang Berhubungan dengan Anemia pada Ibu Hamil di Wilayah Kerja Puskesmas Gajah Mada Tembilahan Kabupaten Indragiri Hilir tahun 2012. Jakarta: FK UI.

Nurjanah Siti., Siti Chadlilorul Qudsiah, Herry Suswanti Djarot. (2012). Hubungan Antara Paritas dan Umur dengan Anemia Pada Ibu Hamil Trimester III Tahun 2012. Semarang: Universitas Muhammadiyah Semarang.

Proverawati, A. (2013). Anemia dan Anemia Kehamilan. Yogyakarta: Nuha Medika.

Ridayanti. (2012). Hubungan tingat pendidikan Ibu Hamil dengan Kejadian Anemia Pada Kehamilan di Puskesmas Banguntapan I Bantul. Yogyakarta: UMY.

Suheimi, M. (2012). Hubungan Tingkat Pendidikan Ibu Hamil Dengan Kejadian Anemia pada Kehamilannya Di Puskesmas Banguntapan 1 Bantul. Jurnal.

Wiknjosastro, H. (2013). Ilmu kebidanan. Jakarta: YBPSP. 